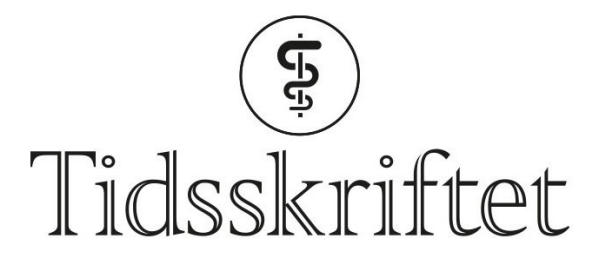

DEN NORSKE LEGEFORENING

\title{
Massebehandling med azitromycin?
}

FRA ANDRE TIDSSKRIFTER

\section{KRISTOFFER BRODWALL}

E-post: kristoffer.brodwall@gmail.com

Barne- og ungdomsklinikken

Haukeland universitetssykehus

Halvårlig utdeling av azitromycin til alle barn under fem år i afrikanske landsbyer førte til færre dødsfall, men slik praksis kan gi økt resistensutvikling.

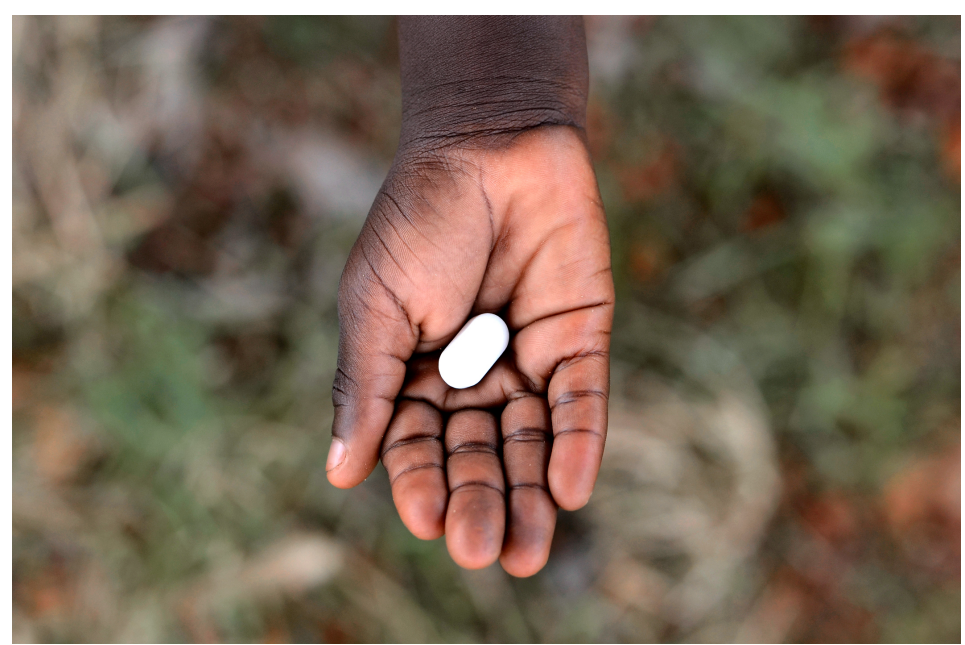

Illustrasjonsfoto: Borgogniels/iStock

Azitromycin er effektivt mot infeksjonssykdommer som malaria, pneumoni og bakterielle tarminfeksjoner, som er vanlige dødsårsaker i Afrika sør for Sahara. Det er derfor blitt foreslått at regelmessig azitromycinbehandling av alle barn i utsatte områder kan redusere dødeligheten. Denne hypotesen ble nylig testet i en studie fra Malawi, Niger og Tanzania (1).

Rundt 1500 landsbyer med 200-2 ooo innbyggere ble klyngerandomisert til tilbud om gjentatte behandlinger med enten azitromycin $20 \mathrm{mg} / \mathrm{kg}$ eller placebo til alle barn mellom én måned og fem år. Midlene ble utdelt med seks måneders mellomrom fra august 2015 til februar 2017. Studien omfattet flere enn 190 ooo barn.

Død uansett årsak ble registrert hos 5020 barn, dvs. en dødelighet på 14,6 per 1 ooo personår i landsbyer der barna hadde fått azitromycin, mot 16,5 der barna hadde fått placebo (13,5\% redusert dødelighet, $95 \%$ KI 6,7-19,8\% p < 0,001). Effekten var størst i aldersgruppen 1-5 måneder, der azitromycinbehandling så ut til å hindre ett av fire dødsfall. Imidlertid var effekten signifikant kun i Niger, som også hadde den høyeste dødeligheten.

- Overforbruk av bredspektrede antibiotika som azitromycin er vist å føre til fremvekst av antibiotikaresistente bakterier, sier Bjørn Blomberg, overlege i infeksjonsmedisin og 
førsteamanuensis ved Haukeland universitetssykehus.

- Flere studier fra Tanzania har vist alarmerende høy forekomst av multiresistente bakterier og over $70 \%$ dødelighet hos barn med sepsis forårsaket av resistente bakterier.

Blomberg støtter massebruk av azitromycin i kampanjer for å utrydde neglisjerte tropesykdommer som trakom og frambøsi (yaws), men er redd for at den nye studien kan tolkes som støtte til massebehandling med antibiotika utover dette.

- Slik praksis vil kunne gi økt resistensutvikling i fattige land, sier han.

LITTERATUR:

1. Keenan JD, Bailey RL, West SK et al. Azithromycin to reduce childhood mortality in sub-saharan Africa. N Engl J Med 2018; 378:1583 - 92. [PubMed][CrossRef]

Publisert: 26. juni 2018. Tidsskr Nor Legeforen. DOI: 10.4045/tidsskr.18.0431

(C) Tidsskrift for Den norske legeforening 2020. Lastet ned fra tidsskriftet.no 